\title{
THE STABILITY OF THE ACHIEVEMENT MOTIVE STRUCTURE AND ITS OPERATIONALIZATION WITH THE SCALE MOP2002
}

\author{
UDC 796.278.2:159.94.5
}

\section{Mirjana Franceško, Jasmina Nedeljković, Branislav Kosanović}

Faculty of Legal and Business Studies dr Lazar Vrkatić in Novi Sad, University UNION, Novi Sad, Serbia

\begin{abstract}
The objective of this paper is to test the stability of construct characteristics and the factorial structure of the achievement motive and the psychometrical characteristics of the instrument MOP 2002. The analyses were performed on a sample comprising 2846 participants of different gender and of different educational profiles. The sample of the participants was made during a period of 15 years in a transitional social context. The instrument MOP 2002 contains 55 items and has the form of a five-level scale. The results of the factor analysis have shown that the instrument is multidimensional and consists of four factors: competing with others, persistence in realizing goals, realizing goals as a source of satisfaction and orientation towards planning. All of these factors are, among others, important for successful participation in competitive sport. By a factor analysis of the second order it was established that the instrument has a unique object of measuring and satisfactory psychometrical characteristics proven stable during 15 years of application on heterogeneous samples of participants.
\end{abstract}

Key words: Achievement Motive, Measuring, Psychometric Characteristics, Sport

\section{INTRODUCTION}

The author of this paper began to study achievement motive, as a complex and significant socio-psychological phenomenon, in the 1990s (Franceško, 1995; Franceško \& Radlovački, 1996). At that time, with modest research experience, but with a clear idea of the significance of the subject, the first steps were taken towards conceptualization and

\footnotetext{
Received May 15, 2019/ Accepted September 26, 2019

Corresponding author: Jasmina Nedeljković

Faculty of Legal and Business Studies dr Lazar Vrkatić in Novi Sad, University UNION, Novi Sad, St. Čarnojevića $10 \mathrm{a}, 18000 \mathrm{Niš}$, Serbia

Phone: +381 18510900 •E-mail: jasmina_djn@yahoo.com 
developing research techniques whose results opened up new research areas and projects. The results of previous research indicating the structure and operationalization of the achievement motive constitute the basis of this work (Franceško, Mihić, \& Bala, 2002; Franceško, Kodžopeljić, \& Mihić, 2002). Thus, we have been exploring achievement motive in a kind of "longitudinal" study conducting an "experiment" in natural conditions and applying the scale on heterogenous samples of participant. We would like to establish the stability of our construct and offer a measuring instrument with a reduced number of items that would retain its fixed factorial structure and satisfactory psychometric characteristics. This research period is not just temporally long, but its social context is especially significant for studying achievement motive called the period of social transition.

Hence, the objective of this work is to test the factorial structure and constructive validity of MOP 2002 after fifteen years of application in research practice, together with broad monitoring markedness and content of each component.

\section{METHODS}

\section{Sample}

The analyses are carried out on a sample comprising 2846 participants, collected over a period of 15 years. The gender structure of the sample is the following: $36.3 \%$ male and $63.7 \%$ female participants, aged between 17 and 45, with an average age of 29 . The data was collected in Northern Serbia (A.P. Vojvodina, 24.2\%), Central Serbia, Suumadija) (35.3\%), South Serbia (19.\%), and Montenegro (20.7\%). From the educational aspect, the sample comprises $47.6 \%$ participants with an elementary or high-school degree and $52.4 \%$ with a higher or university education. From the professional aspect the sample includes high-school and university students and psychologists, educationalists, engineers, lawyers, professors, athletes (professionals and recreational players), English language teachers, musicians, navigation experts, medical doctors, journalists, salesmen, etc.

\section{Measures}

The self-appraisal scale MOP 2002 was applied (Franceško et al., 2002). It comprises 55 items with Likert-type answers. It is a four-factor scale that includes the following factors: competing with others, realization of goals as a source of satisfaction, persistence in the realization of goals, and orientation towards planning. The scale is applicable to persons aged 15 and above. The scale belongs to the category of universal measuring instruments for general achievement motive, not specified for particular spheres of life and work.

\section{Statistical analyses}

The procedure of testing constructive validity, factorial structure and psychometric characteristics of the scale MOP 2002 included two phases: the use of exploratory factor analysis and the application of the programme package RTT9G (Knežević \& Momirović, 1996). 


\section{RESULTS}

The first phase included exploratory factor analysis of four assigned factors which were, in previous research and analyses, defined as competing with others, the realization of goals as source of satisfaction, persistence in the realization of goals and orientation towards planning; shortened for convenience as competition, goal, persistence and planning.

Exploratory factor analysis on four assigned factors with Promax rotation is applied to previously standardized and normalized data. The results are displayed in table 1 .

Table 1 Value of characteristic root and \% of explained variance

\begin{tabular}{crcc}
\hline Factor & Eigen. & \% of Var. & Cum. \% \\
\hline 1 & 11.83 & 21.50 & 21.50 \\
2 & 5.03 & 9.14 & 30.64 \\
3 & 2.52 & 4.59 & 35.23 \\
4 & 1.86 & 3.39 & 38.62 \\
\hline
\end{tabular}

The factors extracted explain $38.62 \%$ of the total system variability and the correlations of separate factors range from .22 to .55 .

The first Promax factor explains $21.5 \%$ of the total variance; table 2 shows manifest items sorted according to intensity of saturation.

Table 2 Manifest items of the first extracted factor

\begin{tabular}{lc}
\hline Items & Factor loadings \\
\hline I have a need to show others how successful I am. & 0.73 \\
I invest a lot of energy to win recognition from others. & 0.72 \\
I aspire to be ahead of all the others. & 0.70 \\
It is important to me to become prominent in what I do. & 0.68 \\
The greatest stimulus for me is to compete with others. & 0.67 \\
If someone is better than I am, I want to catch up with him/her. & 0.65 \\
To be the best - that is a good motto. & 0.64 \\
It is important to me that people speak about my success. & 0.63 \\
In any activity I need to be successful no matter what. & 0.62 \\
I try to be the best in anything I do. & 0.60 \\
It is important to me to gain prominence with my success. & 0.58 \\
I think I am of competitive spirit. & 0.57 \\
Success is the most important thing in life. & 0.56 \\
Mostly, I set very ambitious goals to myself. & 0.53 \\
It is important to me what others think about my achievements. & 0.51 \\
It is important to me how others evaluate my work. & 0.45 \\
When I like a person, I do not give up until I conquer her/him. & 0.37 \\
I do not understand people who pursue success. & -0.22
\end{tabular}

The factor matches the first picked out factor from the research in 2002 perfectly. Then it was called Competition with others. 
The second factor explains $9.14 \%$ of the total system variance and in table 3 the manifest items are shown sorted according to saturation.

Table 3 Structure of the second extracted factor

\begin{tabular}{lc}
\hline Items & $\begin{array}{c}\text { Factor } \\
\text { loadings }\end{array}$ \\
\hline I always persevere in realizing my goals. & 0.69 \\
Even if it is not easy I finish the work I do. & 0.65 \\
I always finish whatever I started. & 0.65 \\
If I do something difficult, I persist through the end. & 0.64 \\
I always accomplish most of the things I planned. & 0.59 \\
I always have some goal in front of me that I want to realize. & 0.59 \\
Every job is a new challenge for me. & 0.57 \\
I know what I want in my life. & 0.57 \\
Even after I fail repeatedly, I do not give up. & 0.56 \\
Other people think of me that I am a sort of person who „knows what he/she wants“. & 0.51 \\
I am ready to take responsibility for the tasks I carry out. & 0.50 \\
I see myself in the future as a successful person. & 0.46 \\
I always learn from my past mistakes. & 0.46 \\
I am bored most of the time. & -0.36 \\
My motto is »leave it for tomorrow what you do not have to do today «. & -0.49 \\
I usually postpone a work if it requires a lot of effort. & -0.51 \\
\hline
\end{tabular}

This is a bipolar factor that, as in the case before, matches perfectly with the second singled out factor in the research 15 years ago, then called Persistence in realizing goals.

The third Promax factor explains $4.59 \%$ of the variability and the items it contains are presented in table 4.

Table 4 Structure of the third extracted factor

\begin{tabular}{lc}
\hline Items & $\begin{array}{c}\text { Factor } \\
\text { loadings }\end{array}$ \\
\hline I feel good when I achieve good results. & 0.69 \\
I hold people who are persistent in accomplishing their goals in high esteem. & 0.66 \\
Even when I only think about accomplishing my goals, it arouses positive feelings in me. & 0.61 \\
I feel great satisfaction when I fulfill my daily plan. & 0.59 \\
In every moment one should have clearly defined goals. & 0.59 \\
Persistence is a human characteristic that I admire. & 0.59 \\
Doing a good job is the greatest reward for me. & 0.58 \\
Success does not happen overnight, but as a result of careful planning and hard work. & 0.57 \\
I always try to work harder than I did before. & 0.56 \\
I admire successful people. & 0.54 \\
I hope for success in any activity I begin. & 0.52 \\
I always learn from my mistakes. & 0.46 \\
\hline
\end{tabular}

This factor is unipolar in content of its items completely matche the third factor in the previous research termed Realization of goals as source of satisfaction. 
The structure of the fourth extracted factor is shown in table 5. It explains $3.39 \%$ of the total variance of the analysed system.

Table 5 The fourth promax factor and the items it contains

\begin{tabular}{lc}
\hline Items & $\begin{array}{c}\text { Factor } \\
\text { loadings }\end{array}$ \\
\hline I plan every activity. & 0.74 \\
I plan my activities for tomorrow. & 0.72 \\
I plan everything thoroughly in order to achieve better results. & 0.68 \\
Every activity ought to be previously well planed. & 0.60 \\
If I do not have a plan for the day, I feel odd. & 0.58 \\
When I achieve one goal, I immediately find another because it fulfils me. & 0.47 \\
If I do not finish what I started, it does not concern me much. & -0.33 \\
I think that it does not make sense to plan a lot of things. & -0.51 \\
My motto is »One should live from one day to the next, there is no need for big plans «. & -0.53 \\
I rather like to be spontaneous, I do not care for too much planning. & -0.61 \\
\hline
\end{tabular}

This is one more bipolar factor that consists of 10 manifest items in total. Complete compatibility with the research from 2002 is confirmed; then it was defined as Orientation towards planning. The matrix of cross correlations of extracted Promax factors with a shortened version of terms is displayed in table 6 .

Table 6 Correlation coefficients between factors

\begin{tabular}{lcccc}
\hline Factors & Competition & Persistence & Goal & Planning \\
\hline Competition & 1.00 & 0.22 & 0.35 & 0.29 \\
Persistence & 0.22 & 1.00 & 0.55 & 0.37 \\
Goal & 0.35 & 0.55 & 1.00 & 0.43 \\
Planning & 0.29 & 0.37 & 0.43 & 1.00 \\
\hline
\end{tabular}

All the obtained correlation coefficients are statistically significant and positive. The highest degree of connectedness is noticed between the factors Persistence in realizing goals and Realizing goals as a source of satisfaction. Identical results are obtained in the above mentioned research from 2002.

The factorial analysis of the second order indicates that there is one factor that explains $53.22 \%$ of the total variability of the system. In table 7 we can observe the saturation of primary factors displayed using shortened forms with this secondary factor.

Table 7 Correlations of factors of the first and second order

\begin{tabular}{lc}
\hline Factors of the first order & General factor of the second order \\
\hline Competition & .59 \\
Persistence & .76 \\
Goal & .83 \\
Planning & .72 \\
\hline
\end{tabular}

All four factors of the first order are in a statistically significant high positive correlation with the factor of the second order exactly as it could be predicted from the previous research. 
This apparently indicates that MOP 2002 has a unique object of measuring, in other words, that Competition, Persistence, Goal and Planning are not separate dimensions of, but together constitute the general achievement motive.

The second phase of the research includes the application of the programme package RTT9G aiming at testing the psychometric characteristics of the scale MOP 2002. The results of this analysis are shown in table 8. In the table the results taken from the 2002 research are presented alongside.

Table 8 Psychometric characteristics of the scale MOP2002

\begin{tabular}{lcc}
\hline The measure of representativeness of the test: & \multicolumn{2}{c}{ MOP2002 } \\
\cline { 2 - 3 } & 2002. & 2017. \\
\hline Kaiser-Mayer-Olkin, measure of representativeness, PSI 1 & .92 & .98 \\
Kaiser, Rice, measure of representativeness, PSI 2 & .91 & .98 \\
\hline The measure of reliability under the classical summation model: & & \\
$\quad$ Spearman-Brown-Kuder-Richardson-Guttman-Cronbach, ALPHA & .91 & .93 \\
\hline The measure of reliability of the first major component: & .92 & .93 \\
$\quad$ Lord-Kaiser-Caffrey, BETA & .81 & .84 \\
Momirović-Dobrić-Gredelj, lower limit of reliability, BETA 1 & .99 & .99 \\
Momirović-Dobrić-Gredelj, upper limit of reliability, BETA 2 & & \\
The measure or reliability under Guttman's mesurement model: & .94 & .95 \\
Guttman-Nicewander, RHO & .89 & .90 \\
Momirović-Dobrić, lower limit of reliability, RHO 1 & .99 & .99 \\
Zakrajsek-Momirović-Dobrić, upper limit of reliability, RHO 2 & & \\
\hline The measures of homogeneity of tests: & .16 & .19 \\
$\quad$ Average correlation of variables, H 1 & .44 & .50 \\
\hline Momirović, measure of homogeneity, H 2 & & \\
\hline
\end{tabular}

On the basis of these results we can conclude that the reliability of the scale MOP2002 is very high (alpha=.93), as well as the reliability of the first major component (beta=.93). Both coefficients are somewhat higher than those obtained in the research from 2002 and that confirms that the reliability of MOP remained consistent and satisfactory. Both indicators of representativeness (PSI1=.98; PSI2=.98) are even significantly higher than those obtained 15 years ago. We can justifiably claim that MOP 2002 belongs to the group of measuring instruments with the highest degree of representativeness. This indicates that the items MOP consist of are highly informative, so that, even if it was possible to collect data using an infinite list of questions, this quality would hardly be expected to increase. If we consider the relative magnitude of the variance of the first major component items transformed into image form, we can observe that MOP 2002 has a satisfactory degree of homogeneity perfectly corresponding to the analysis from 2002.

\section{DISCUSSION}

The systematic study of achievement motive was initiated by McClelland's pioneering work (McClelland, Atkinson, Clark, \& Lowell, 1953). He and his associates pointed out the significance and complexity of investigating social motivation. As basic social motives he singled out the achievement motive, the affiliation motive and the power motive. We believe 
that these motivational dispositions are relatively stable, molded in socialization, since they heavily influence both the social behaviour of individuals and the society as a whole. In a number of works (Heckhausen, 1991; Thrash, Elliot, \& Schultheiss, 2007; Elliot \& Murayama, 2008; Schuler, Sheldon, \& Frohlich, 2010; Xu, Xu, Mellor, \& Duan, 2012; Bipp \& van Dam, 2014; Baghteyfouni, 2016); the authors make efforts to determine individual differences in the degree of markedness which further determine the differences in perception and behavior.

McClelland focused on the achievement motive, which he defines as the tendency of the individual to compete with some standard of exceptional successfulness or as aspiration to surpass one's own or somebody else's accomplishment (McClelland, 1961; McClelland, 1984; McClelland, 1985; McClelland, Atkinson, Smith, Atkinson, McClelland, \& Veroff, 1992; McClelland \& Koestener, 1992; McClelland, 1998).

The basic social motives are frequently termed implicit (McClelland, 1985; McClelland, Koestener, \& Weinberger, 1989; Schultheiss, \& Hale, 2007), thus emphasizing that these are inner dispositions that significantly influence the behavior of the person. This theoretical premise influenced the orientation of researchers in their endeavors to find adequate measuring methods, in other words, methods of determining individual differences regarding achievement motive. The research is dominated by applying projective techniques of indirect measurement grounded on interpretation of social situations through a prism of what in general determines the motive, and that is a tendency towards success. In spite of there being a considerable number of studies attempting to make the notion tendency towards success more precise (McClelland et al., 1953; Elliot \& McGregor, 2001; Elliot \& Fryer, 2008; Baranik, Stanley, Bynum, \& Lance, 2010), a lot of questions remained open; for instance, what, in a psychological sense, achievement means; which psychological mechanisms, processes and personal traits it comprises; what individual differences regarding content we take as significant, in other words, what is it for an individual to be successful, which personal and social factors determine the content and function of success; wherein lies the difference between tendency and realized achievement and what determines, to a lesser or greater degree, this incongruence and what consequences brings this about; what, apart from projective techniques, can we use to measure this motivational disposition. In an attempt to find answers to some of these questions we began with the assumption that achievement motive is a complex social motivational disposition whose understanding and thereby setting of the guidelines for personal and socially acceptable development requires additional research in some specific social context. Moreover, adequate models to operationalize and measure are needed.

In the definition of achievement motive given above the prefix social may be understood in several different ways. Firstly, it indicates that socialization plays a dominant role in its development. Secondly, it refers to its social character in the axiological sense that it reinforces socially desirable behavioral tendencies in some cultural milieu. Finally, it designates the specific quality of interpersonal relationships in which the individual differences in social behavior are affected by this motivational disposition. If these individual differences are more or less well-balanced regarding their intensity and content they may serve as guidelines and/or become a distinguishing feature of some culture. Although, we believe that it is very important to make these distinctions between different meanings of social motives in the study of Man and his/her behavior, it is almost impossible to establish clear boundaries between these three meanings. 
Our further arguments in the study of achievement motive will represent some sort of integrative approach emphasizing sometimes the sense factor, sometimes value and/or the influence of this motivational disposition on social behavior.

If the achievement motive is defined as one of the basic motivational dispositions then it implies, among other things, the general omnipresent coloring that, as it were, permeates the individual's experience of the social world and his/her global personal and social orientation towards a desired future achievement. This point of view, we believe, closes the gap between the notions of basic value disposition and value orientation. For, we define values as complex positive attitudes a person has towards fairly generic and relatively abstract, but desirable states-of-affairs and modes of behavior. The directedness towards desirable states gives values the forms of goals in life...their function is that of orientation and integration of past, present and future behavior of the person. When directed towards future events, values determine our expectations... the values as cognitive structures are the foundations for evaluative appraisal of past and present events (Franceško, 2014. p. 5-6). In the context of investigating achievement motive, the general expectation is directedness towards realizing goals, and/or surpassing some standard of successfulness, and as an orientation it is relatively stable. The evaluation component would mean experiencing events and accomplishments in the perspective of some quality measure or previously anticipated criterion of achievement. Perhaps, this idea of bringing the concepts of basic motivational disposition and values closer together is the right way of searching for additional explanations of the role that cultural milieu plays in influencing motivational content at the individual as well as at the social level. What the cause is and what the effect in this synergy is, the question initiated by McClelland and his associates (McClelland, 1961) is still unanswered.

In any case, without entering deeper into the explanation of this interaction of factors, for any investigation of achievement motive social context is indispensable. Our point of view is that the determination of content of three basic motives can be an important criterion for defining differences in cultural patterns both on national and organizational level.

Assuming that social context is indispensable, we began our long-lasting investigation of achievement motive in a society in transition for which it is characteristic that the system of values keeps changing. This process of transformation of the value system in the social context wherein our research is carried out lasted for a very long time. These changes in the society wandered in various directions from a changing social system, borders, ownership structure to development and recession, from wartime destruction to an enthusiastic upsurge and after that quick desist, which always meant a painful fallback to an even lower level from the one from which the "reforms" started. The aim of our research was to define achievement motive as an individual characteristic. However, because it is essentially social, in all the different senses of the word, from determination factor causing events, to influencing social development in general created by people, the results of our research can indicate certain cultural determinants via the degree of development and content of the tendency towards achievement in a certain time-frame.

Turning to one of our tasks in our research project, whose aim is monitoring the stability of the factorial structure of our construct and the psychometric characteristics of the constructed instrument which we have tested in different social contexts, the results indicating its stability would be particularly significant.

The achievement motive is a complex motivational disposition connected mostly with the conative aspect of a person. There are also a number of works investigating its cognitive 
and emotional aspects (Elliot \& Church, 1997; Elliot \& McGregor, 2001; Brunstein \& Heckhausen, 2008). The argumentation for using the prefix "cognitive" was implicated by McClelland's definition and method of measurement (he was followed by other authors); the question to be answered was whether cognitive processing of information in experiencing social situations dominantly includes achievement. Competition with some standard of successfulness certainly implies some criteria and measure of appraisal; and these are evidently cognitive processes. Both components, especially the one which Pajares, Britner, and Valiante (2000) call tendency towards setting goals, implies some operationalization of desire through some concrete and measurable progress and that involves the process of anticipation as well as a very important cognitive process of temporal perspective, in this context directed towards experiencing future. Cognitive processes are also included in situations in which success is defined on the basis of comparison of one's own achievement with achievement of others as a competition, since competing with others entails comparison. The cognitive aspects are present not only in measuring exceptional success, but also in perceiving problems or appraising current and desirable states-of-affairs and thinking about the possible ways of overcoming them.

Having in mind segments of the above mentioned line of argumentation regarding cognitive aspects of the achievement motive, we singled out three components of the achievement motive: realizing goals as a source of satisfaction, competition with others, and a tendency towards planning.

An important segment of achievement motive is emotional experience, regardless whether it functions as a stimulative or inhibitive factor, or as experiencing satisfaction with realized or anticipated goals. In the literature, authors focused mostly on dysfunctional, disturbing emotional experiences regarding achievement situations, studied by Atkinson in the context of stage fright, fear of failure etc., and termed procrastination (Atkinson \& Raynor, 1974; Heckhausen, 1963).

Our point of view that cognitive and emotional aspects are significant for exploring achievement motive, and we singled out persistence as one of its components. Persistence is an implement that stabilizes emotional turmoil in achievement situations, its effect being one of the most important motivational dispositions that include overcoming unpleasant emotional reactions, guided by rational decision in problem solving and achieving satisfaction as a positive enforcement for reaching some standard of exceptional successfulness. Persistence is a resultant of emotional turmoil typical for achievement situations and other personal traits that may be the condition or the effect of individual success history.

Summing up our arguments and the results of our research we define achievement motive as an aspiration to become successful. It does not make any difference whether success is defined as the realization of one's goals and/or standing out from other people (Franceško et al., 2002). Together with the defining criteria of successfulness, it is necessary to detect individual differences regarding tendency towards planning and persistence in realizing goals. Since the beginning of sport psychology as a discipline within psychology, attention in research has been focused on the motivation for achievement, representing it as a central feature in which top athletes differ from others (Ogilvie \& Tutko, 1966; Cratty, 1973). The results of classical research (Roberts, 1982) show that athletes with high achievement motivation choose tasks of moderate difficulty, and recent studies (dealing with the motivational profile of top athletes) show that top athletes are dedicated, confident about 
their abilities, and intrinsically motivated (Hodge, Allen, \& Smellie, 2008). The expression of the achievement motive obtained by this instrument could serve for the purpose of selection in a sport like introversion (Morgan, 1985), perfectionism (Bojanić, Šakan, \& Nedeljković, 2018), anxiety (Raglin, 2001), etc.

On the face of it, there are a lot of methods or instruments for measuring achievement motive (Murreay, 1943; McClelland, 1961; Heckhausen, 1963; Harackiewicz, Sansone, \& Monderling, 1985; McClelland, 1998; Schmalt, 1999; Puca \& Schmalt, 1999; Sokolowski, Schmalt, Langens, \& Puca, 2000; Puca \& Schmalt, 2001; Smith, Hunnicutt Hollenbaugh, \& Arora, 2014; Baghteyfouni, 2016). However, we agree with Smith (Smith, 2015) who emphasizes the need for the further development of the method for appraising achievement motive. Methodological solutions so far are based on projective techniques and techniques of self-evaluation using the instrument paper-and-pencil. Our proposal operationalizing achievement motive is to construct a universal instrument for measuring this motivational disposition with clearly defined factorial structure. The form of the instrument would be dual; namely, it can be used in paper-and-pencil form and be based on the self-evaluation of participants, and, on the other hand, the abridged version MOP 2002 can be taken as a kind of protocol for observation and appraisal of the behavior of the person designed to determine the degree and profile of the achievement motive within a certain period of time. This would open the possibility of testing the congruity between the person's self-appraisal and the evaluation of the person by other relevant subjects regarding achievement motive. The necessary condition for the construction of such an instrument is the test of the stability of the construct which is the initial intention and the primary objective of this work.

Why is the development of such an instrument important for athletes? There is a tendency that all questionnaires used in a sports context must be sport-specific, but it should be noted that the results of some research indicate that the general achievement motivation can be successfully used in work with athletes. Although they point to the existence of a specific motive of sport achievement (besides the general achievement motive), Havelka and Lazarević (1981) get a solid correlation between the scores on these scales (in top athletes 0.56, in standard ones 0.53). Also, Duda and Nicholls (1992) report on the common foundations of achievement in school and sport situations. On the other hand, this instrument can be used for monitoring of achievement motivation for former athletes of all ages, keeping in mind that in sport psychology it is not just about how psychological characteristics influence sport performance, but also how participation in sport affects the development of psychological characteristics of an individual. A powerful, persistent achievement motivation that an athlete should transfer to everyday life is one of the most important aims of sports.

The objective of this work is to test the factorial structure and constructive validity of MOP 2002 after fifteen years of application in research practice. This way an adequate measuring instrument would be obtained that would be less engaging for the participant. For this effort it was necessary to exploit the original instrument MOP 2002 during a longer period on a sample of participants sufficiently large and diverse. The assumption is that a sufficiently long exploitation and temporal distance between the initial application and testing its factorial structure and metrical characteristics, and the period of 15 years in a transitional society, as a significant factor of social motivation, re relevant facts regarding the stability of the construct as well of the measuring instrument. 
The results of our research confirmed the initial theoretical construct of the achievement motive. This was the basis for factorization on 4 assigned factors. The ones picked out were: competing with others, the realization of goals as source of satisfaction, persistence in realization of goals, and orientation towards planning; they explain $38.62 \%$ of the variance. The extracted factors content-wise correspond entirely to the factors obtained in the research from the year 2002. They indicate that the achievement motive has a complex nature and that it is necessary to monitor all the separate components. Moreover, it further implicates that it is not sufficient to determine the general score, but that it is necessary to establish the profile of the participants in separate dimensions, in order to determine individual differences. We claim that the significant individual differences in social behavior based on achievement motive are due to differences in profiles of the construct.

This conclusion is warranted also by the results obtained concerning the connection among the separate components of the achievement motive. Although all the correlation coefficients are statistically significant and positive, a more in-depth analysis of coefficient magnitude indicates certain tendencies. Orientation to planning and persistence, conceived as instrumental forms of reaction relevant to achieving success, are more closely connected with realization of goals as source of satisfaction than to competing with others as a way of defining success. In other words, we began with the assumption that there are at least two ways of measuring personal achievement; firstly, on the basis of goals set and achieved and/or secondly, in competition with other people's achievements. The correlation between these two factors is statistically significant, but the magnitude of the coefficient $r=.35$ leaves enough variability that can be interpreted as real individual differences in subjective criteria for evaluating success. This conclusion is corroborated by the results obtained considering connections between instrumental forms of behavior with both, orientation to setting goals and competing with others, which are significantly stronger in the case of the former, than in the case of the latter; taken together these confirm the initial assumption.

The results of the second order factor analysis confirm that the scale MOP 2002 has a unique object of measuring and that the four dimensions picked out together constitute the achievement motive. However, not counting the fact that all first order factors are statistically significantly and positively connected to the second order factor, the differences regarding the correlation coefficient magnitude seem to be significant and deserve a short interpretation. The highest degree of connectedness has the tendency towards realizing goals as source of satisfaction. Second to that are persistence and orientation to planning as instrumental forms of behavior, which are connected to directedness towards goals to a lesser degree. In this context the relatively lowest degree of connectedness to the second order factor has the tendency towards competing with other people. This can be interpreted as a striking tendency of our participants to define directions and criteria of success as the source of satisfaction by means of setting goals. However, there is a question concerning the possibility of satisfying this tendency in a transitional society, since there is no clearly determined system of values, no strategies of social development and instead of future planning, it is dominated by analyzing past events. In such a social environment, we suspect, personal potentials of the achievement motive are rather sources of frustration, not of fulfilment for the individual as well as for the community as a whole, and could be taken as one of the reasons for its stagnation. From the point of view of social development the question is how can this identified potential become a driving force in the development of society; what is missing on the personal or social level that prevents this motivational 
potential from becoming a socio-psychological factor in the development of the country in which we carried out this research project - that, however, remains an open question.

The differences in magnitude of correlation coefficient among separate components within achievement motive indicate that it is indispensable to determine the profile of this motivational disposition. The degree of markedness is just an indicator of the intensity, in other words, how important orientation towards achievement is for the person as a segment of his/her motivational and value system. For understanding as well as predicting a person's success, the diagnosis of markedness considering each component of the achievement motive is indispensable. Generally speaking we can estimate the degree of congruency or incongruency between the four components; thus, for example, if a person's goals are set and his activities are accompanied with careful planning, if she/he is able cognitively and emotionally to find ways to overcome many difficulties on his/her way to success, the degree of probability of achievement as the final outcome is much higher. The opposite to this is a person whose achievement motive profile is characterized by vivid tendency to set high standards of exceptional success, but without sufficient degree of motivation which is related to instrumental forms of behavior such as organization of activities by planning and persistence. These results motivate further research into some of the typical profiles of the achievement motive.

Considering the instrument MOP2002, the results show its relative stability. Most of the psychometric indicators are rather good and there is no discrepancy between these and the results obtained at the time of construction. The conclusions presented open the possibility of further work on the instrument with the goal of reducing the number of items and in the same time preserving the structure and degree of informativeness. The reducing of items will lead, we assume, to more efficient engagement of the participants and the use of abridged versions of the scale in separate batteries of the instrument to a broader application in measuring complex psychological phenomena such as organizational culture, traits of 'successful' leaders, professional, academic and competitive achievements. The contrastive index, where self-evaluation results are put side-by-side with appraisals of others - educated observers - contributes to elevating the degree of objectivity in measuring achievement motive. A higher degree of diagnostic precision is necessary for work with individuals in order to develop a functional achievement motive, as well as to predict academic or professional behavior. Diagnostics or an intervention should imply taking care of individuals, and the guidelines to this activity can be found in specific profiles of the achievement motive based on markedness and combinations of its four components.

An additional motivation for refining and abridgment of this instrument are not only obtained from this project, but also inspired by the fact that a construct so defined and the scale MOP 2002 found broad application in solving various problems in projects carried out in Serbian speaking regions. Thus, for example, the scale was applied in studying competitive phenomena, sport in particular (Sindik, 2008; Sindik \& Puljić, 2010; Sindik, 2010; Ivanišević, Vlašić, \& Čolakhodzić, 2017), organizational culture (Bubulj, Arsenijević, \& Simić, 2011), and personality structure (Mihajlović \& Stojanović, 2014; Kalajdžić, 2017). Further work in perfecting MOP 2002 is motivated by opening of the possibilities that its abridged version may be used in a broader area where similar languages are spoken and where cultural paradigms overlap. It is our intention to present the abridged version of the scale in some future work. A shortened version would facilitate both practical and research use, especially for athletes. 


\section{CONCLUSION}

The years devoted to investigating and monitoring achievement motive were at the same time devoted to testing the stability of this construct and measuring instrument. The contrastive analysis of parameters during a considerable period through a very variable social context has shown the relative stability of structure and operationalization of the achievement motive in the same way we did more than fifteen years ago. Does that mean that we are on the right track to extract the basic part of the achievement motive in the sense of motivational and valuation directedness of human beings in their struggle for goodness and efficiency, which was not influenced by, according to our results, the extreme and frequently destructive social factors of social transition in Serbia and the surrounding countries?

\section{REFERENCES}

Atkinson, J.V., \& Raynor, J.O. (1974). Motivation and achievement. Washington, DC: John Wiley.

Baghteyfouni, Z.K. (2016). Construction and standardization of Achievement Motive Test among high school students in the city of Tehran. International Journal of Pharmaceutical Research \& Allied Sciences, 5(3), $182-186$.

Baranik, L.E., Stanley, L.J., Bynum, B.H., \& Lance, C.E. (2010). Examining the construct validity of mastery avoidance achievement goals: A meta-analysis. Human Performance, 23, 265-282.

Bipp, T., \& van Dam, K. (2014). Extending hierarchical achievement motivation models: The role of motivational needs for achievement goals and academic performance. Personality and Individual Differences, 64, 157-162.

Bojanić, Ž., Šakan, D., \& Nedeljković, J. (2018). Personality traits as predictors of perfectionism. Facta Universitatis Series Physical Education and Sport, 16(1), 57-71.

Brunstein, J.C., \& Heckhausen, H. (2008). The achievement motive. In H. Heckhausen \& J. Heckhausen (Eds.) Motivation and action. Cambridge, UK: Cambridge University Press.

Bubulj, M., Arsenijević, O., \& Simić, J. (2011). Connection between organizational culture and development of achievement motive of students of the faculty of management. Educational Research and Reviews, 6(6), 481-488.

Cratty, B.J. (1973). Teaching motor skills. Prentice Hall.

Duda, J.L., \& Nicholls, J.G. (1992). Dimensions of achievement motivation in schoolwork and sport. Journal of Educational Psychology, 84(3), 290.

Elliot, A.J., \& Church, M.A. (1997). A hierarchical model of approach and avoidance achievement motivation. Journal of Personality and Social Psychology, 72, 218-222.

Elliot, A.J., \& Fryer, J.W. (2008). The goal concept in psychology. In J. Shah \& W. Gardner (Eds.), Handbook of motivational science, (pp. 235-250). NY: Guilford Press.

Elliot, A.J., \& McGregor, H.A. (2001). A 2x2 achievement goal framework. Journal of Personality and Social Psychology, 80, 501-519.

Elliot, A.J. \& Murayama, K. (2008). On the measurement of achievement goals: Critique, illustration, and application. Journal of Educational Psychology, 100(3), 613-628.

Franceško, L.M. (2014). Vrednosne orijentacije mladih u Vojvodini: stanje i perspektive (Value orientations of youth in Vojvodina: Status and perspectives). In M. Franceško (Ed.), Value orientations of youth in Vojvodina: Status and perspectives. (pp. 5-9), Novi Sad: Faculty of Legal and Business Studies Dr Lazar Vrtakić. In Serbian

Franceško, M. (1995). Motivacija, struktura motiva, motiv postignuća. Book of the Proceedings: Sistem kvaliteta. (pp. 13-21), Novi Sad: University of Novi Sad, Research and Technology Center. In Serbian

Franceško, M., \& Radlovački, V. (1996). Motiv postignuća rukovodilaca (Achievement motive of managers). Proceedings of the 10th International Conference Industrial Systems, (pp. 65-71). Novi Sad: Faculty of Technical Sciences, Institute of Industrial Systems. In Serbian 
Franceško, M., Kodžopeljić, J., \& Mihić, V. (2002). Neki socio-demografski i psihološki korelati motiva postignuća (Some socio-demographic and psychological correlates of achievement motive). Psihologija, 35, 65-79. In Serbian

Franceško, M., Mihić, V., \& Bala, G. (2002). Struktura motiva postignuća merena skalom MOP2002, Ličnost u višekulturnom društvu (Structure of achievement motif as measured by the MOP2002 scale, Personality in a multicultural society). In B. Čukić, \& M. Franceško (Eds.). Organizacijska multikulturalnost i evropski identitet (Organizational multiculturalism and European identity), (pp. 134-143). Novi Sad: Faculty of Philosophy, Department of Psychology. In Serbian

Harackiewicz, J. M., Sansone, C., \& Monderling, G. (1985). Competence, achievement orientation, and intrinsic motivation: A process analysis. Journal of Personality and Social Psychology. 48, 493-508.

Havelka, N., \& Lazarević, L. (1981). Sport i ličnost (Sport and personality). Sportska knjiga. In Serbian

Heckhausen, H. (1963). Hope and fear components of achievement motivation. Meisenheim am Glan, Germany: Anton Hain.

Heckhausen, H. (1991). Motivation and action. NY: Springer-Verlag.

Hodge, K., Allen, J.B., \& Smellie, L. (2008). Motivation in Masters sport: Achievement and social goals. Psychology of sport and Exercise, 9(2), 157-176.

Ivanišević, D., Vlašić, A., \& Čolakhodžić, E. (2017). Achievement motivation among athletes and nonathletes students. Sportski logos. 15, 5-11.

McClelland, D.C. (1961). The achieving society. NY: Van Nostrand.

McClelland, D.C. (1984). Motives, personality, and society: Selected papers. NY: Praeger.

McClelland, D.C. (1985). Human motivation. NY: Cambridge University Press.

McClelland, D.C. (1998). Identifying competencies with behavioral event interviews. Psychological Science, 9(5), 331-339.

McClelland, D.C., Atkinson, J.W., Clark, R.A., \& Lowell, E.L. (1953). The achievement motive. NY: AppletonCentury-Crofts.

McClelland, D.C., \& Koestener, R. (1992). The achievement motive. In C. P. Smith et al. (Eds.), Motivation and personality: Handbook and thematic content analysis, (pp. 143-152). NY: Cambridge University Press.

McClelland, D.C., Koestener, R., \& Weinberger, J. (1989). How to self attributed and implicit motives differ? Psychological Review, 96 (4), 690-702.

Mihajlović, A., \& Stojanović, A. (2014). Osobine ličnosti i motiv postignuća kod studenata psihologije (Personality traits and achievement motives in students of psychology), Godišnjak za psihologiju, 11(13), 79-96. In Serbian

Morgan, W.P. (1985). Selected psychological factors limiting perfor-mance: a mental health model. In. DH Clarke \& HM Eckert (Eds.). Limits of human performance, (pp. 70-80). Champaign (IL): Human Kinetics.

Murreay, H.A. (1943). Thematic apperceptive test manual. Cambridge: Harvard University Press.

Kalajdžić, O. (2017). Korelacija između psiholoških karakteristika adolescenata i njihovog straha od budućnosti (Correlation between adolescent psychological characteristics and their fear of the future). Biomedicinska istraživanja, 8(2), 144-152. In Serbian

Ogilvie, B.C., \& Tutko, T.A. (1966). Success phobia. In GH Sage. Sport and American Society, (pp. 217-235). MA: Addison-Wesley.

Pajares, F., Britner, C.L., \& Valiante, G. (2000). Relation between achievement goals and self-beliefs of middle school students in writing and science. Contemporary Educational Psychology, 25, 406-422.

Puca, R.M., \& Schmalt, H.D. (1999). Task enjoyment: A mediator between achievement motives and performance. Motivation and Emotion, 23, 15-29.

Puca, R.M., \& Schmalt, H.D. (2001). The influence of the achievement motive on spontaneous thoughts in preand post-decesional action phases. Personality and Social Psychology Bulletin. 27, 302-308.

Raglin, J.S. (2001). Psychological factors in sport performance. Sports Medicine, 31(12), 875-890.

Roberts, G.C. (1982). Achievement motivation in sport. Exercise and Sport Sciences Reviews, 10(1), 236-269.

Schmalt, H.D. (1999). Assessing the achievement motive using the grid technique. Journal of Research in Personality, 33, 109-130.

Schuler, J., Sheldon, K.M., \& Frohlich, S.M. (2010). Implicit need for achievement moderates the relationship between competence need satisfaction and subsequent motivation. Journal of Research in Personality, 44, $1-12$.

Schultheiss, O.C., \& Hale, J. (2007). Implicit motives modulate attentional orienting to facial expressions of emotion. Motivation and Emotion, 31, 13-24

Sindik, J. (2008). The relationship between some psychological characteristics and sport performance of elite zoung bowling athletes, Hrvatski Športsko-medicinski Vjesnik, 23, 93-97 
Sindik, J. (2010). Taxonomic analysis of conative features and competitive success of top shot-put athletes of both gender. Zbornik radova Međimurskog veleučilišta u Čakovcu, 1 (2), 71-77. In Croatian

Sindik, J., \& Puljić, V. (2010). Attitudes towards leisure time motivation at plazers in "SOKAZ" table tennis recreational leagues. Acta Kinesiologica, 4(1), 49-53.

Smith, C.P., Atkinson, J.W., McClelland, D.C., \& Veroff, J. (1992). Motivation and personality: Handbook of thematic content analysis. NY: Cambridge University Press.

Smith, R.L. (2015). A Contextual Measure of Achievement Motivation: Significance for Research in Counseling. In Ideas and research you can use: VISTAS 2015. Retrieved from on July 15, 2017 from the World Wide Web: http://www.counseling.org/knowledge-center/vistas

Smith, R.L., Hunnicutt Hollenbaugh, K.M., \& Arora, S. (2014). Evidence-based practices and single-subject research designs in counseling. In Ideas and research you can use: VISTAS 2014. Retrieved from on July 15, 2017 from the World Wide Web: http://www.counseling.org/knowledge-center/vistas

Sokolowski, K., Schmalt, H.D., Langens, T.A., \& Puca, R.M. (2000). Assessing achievement, affiliation and power motives all at once - The multi-motive grid (MMG). Journal of Personality Assessment, 74, 126-145.

Thrash, T.M., Elliot, A.J., \& Schultheiss, O.C. (2007). Methodological and dispositional predictors of congruence between implicit and explicit need for achievement. Personality and Social Psychology Bulletin, 33(7), 961-974.

Xu, X., Xu, Y., Mellor, D., \& Duan, L. (2012). Motivation and social contexts: A cross-national pilot study of achievement, power, and affiliation motives. International Journal of Psychology, 47(2), 111-117.

\section{STABILNOST OSTVARENOSTI MOTIVACIONE STRUKTURE I OPERACIONALIZACIJA SKALOM MOP2002}

Cilj ovog rada je ispitivanje stabilnosti konstruktivnih karakteristika i faktorske strukture ostvarenosti motiva i psihometrijskih karakteristika instrumenta MOP 2002. Analize su sprovedene na uzorku od 2846 učesnika različitog pola i različitih obrazovnih profila. Uzorak ispitanika je sačinjen tokom perioda od 15 godina u tranzicionom društvenom kontekstu. Instrument MOP 2002 sadrži 55 itema i ima oblik skale od pet nivoa. Rezultati faktorske analize pokazali su da je instrument višedimenzionalan i da se sastoji od četiri faktora: takmičenja sa drugima, upornost u realizaciji ciljeva, ostvarivanje ciljeva kao izvora zadovoljstva i orijentacija prema planiranju. Svi ovi faktori su između ostalog važni za uspešno učešće u takmičarskom sportu. Faktorskom analizom drugog reda utvrđeno je da instrument ima jedinstven objekat merenja i zadovoljavajuće psihometrijske karakteristike koje su se pokazale stabilnim tokom 15 godina primene na heterogenim uzorcima učesnika.

Ključne reči: motiv ostvarenja, merenje, psihometrijske karakteristike, sport 